\title{
Effect of Pre-harvest Treatments on the Cellulase Activity and Quality of Ber Fruit Under Cold Storage Conditions
}

\author{
Sukhjit Kaur JAWANDHA, B. V. C. MAHAJAN, Parmpal Singh GILL \\ Punjab Agricultural University, Department of Horticulture, Ludhiana 141004; punjabbeauty2000@rediffmail.com
}

\begin{abstract}
Studies were carried out to find out the effect of various pre-harvest treatments such as $\mathrm{CaCl}_{2}(0.5 \%, 1.0 \%$ and $2.0 \%), \mathrm{Ca}\left(\mathrm{NO}_{3}\right)_{2}$ (0.5\%, 1.0\% and 2.0\%), $\mathrm{GA}_{3}(20,40$ and $60 \mathrm{ppm})$ and Bavistin $(0.1 \%)$ on the cellulase activity and quality of 'Umran' ber fruits during cold storage. Marked trees were sprayed at colour break stage with the test chemicals. Fruits were packed in CFB boxes and placed in cold storage $\left(3-5{ }^{\circ} \mathrm{C}\right.$ and $\left.85-90 \% \mathrm{RH}\right)$ for 30 days. The fruits were evaluated after 10, 20 and 30 days interval for various parameters such as cellulase activity, phenolics content, palatability rating and rotting percentage. Cellulase activity registered a gradual increase upto 20 days of storage thereafter a decline was noted in all the treatments. The palatability rating increased up to 10 days of storage in all the treatments, except control but subsequently it decreased with an advancement in storage period. Among the various pre-harvest treatments $\mathrm{CaCl}_{2}(2 \%)$ recorded minimum cellulase activity and rotting percentage and have also registered high palatability rating and phenolics content during cold storage conditions. Studies showed that pre-harvest application of $\mathrm{CaCl}_{2}(2 \%)$ maintained very good fruit quality and prolonged shelf-life for 20 days under cold storage conditions.
\end{abstract}

Keywords: ber, storage, cellulase, calcium, $\mathrm{GA}_{3}$

\section{Introduction}

$\operatorname{Ber}($ Zizyphus mauritiana Lamk) is a hardy fruit, which can thrive well under adverse edaphic and climatic conditions. It is nutrition - rich fruit, a tally of nutrititive worth of ber with apple reveals that it excels in calcium, phosphorus and vitamin $\mathrm{C}$ but has comparatively low market price and therefore, referred as poor man's apple. It is an ideal fruit for cultivation in the arid and semi arid zones of northern India, as it has the negligible irrigation requirement in the month of May-June. High yielding cultivar 'Umran' is commercially grown in Northern India. During its peak harvesting season there is usually a glut in the market with a crash in its market price and low returns to the growers. Like most of other fruits, ber is perishable in nature and after harvesting, it cannot be stored for longer period under ambient conditions (Salunkhe and Kadam, 1995). During storage the rotting of fruit depends upon the activity of cellulase enzyme. Higher activity of this enzyme results in fruit softening which subsequently leads to the decay of the fruits. Cellulase is considered to be responsible for the hydrolysis of cellulose fibrils of the cell wall (Babbita et al., 1973). Calcium compounds extends the shelf-life of several fruits by maintaining fruit firmness, minimizing rate of respiration, protein breakdown and disease incidence (Gupta et al., 1980). Calcium is important in the maintenance of cell wall integrity in plants. Heavy influx of external or internal calcium inhibits ripening process due to reduction in enzymatic activity. Similarly certain growth regulators like gibberellic acid are known to promote the shelf life of fruits. Mehta et al. (1986) reported that GA3 $100 \mathrm{ppm}$ significantly suppresses the succinate activities of malate-dehydrogenase during post-harvest ripening of papaya and thus retard ripening. The growers can be greatly benefited if storage health is maintained by application of these compounds. Therefore, the present studies were conducted to investigate the effect of per-harvest application of various chemicals on change in cellulase activity and fruit quality during cold storage.

\section{Materials and methods}

The present investigations were carried out in the department of Horticulture Punjab Agricultural University Ludhiana, during 2002-03 on Umran trees of uniform vigour. The chemicals viz; $\mathrm{CaCl}_{2}(0.5,1.0$ and 2,0\%), $\mathrm{Ca}\left(\mathrm{NO}_{3}\right)_{2}(0.5,1.0$ and $2,0 \%)$ and $\mathrm{GA}_{3}(20,40$ and 60 ppm) were sprayed on the trees at the colour break stage. All the experimental trees, except control, were sprayed with Bavistin (0.1\%) 15 days before harvesting. Eleven treatments including control were laid out in completely randomized design with three replications.

Fruits were harvested at optimum maturity from the representative trees. One $\mathrm{kg}$ fruit from each replication of respective treatment was packed in netlon carriers. Thereafter, the packed fruits were placed in corrugated fibre board (CFB) boxes ( $5 \%$ perforations) with paper lining and kept in cold storage (temperature $3-5^{\circ} \mathrm{C}$ and R.H-85- 
90\%). Fruit samples were analysed for physico-chemical characteristics after 10, 20 and 30 days of storage. Palatability rating (PR) was recorded on the basis of score card viz: 1-poor; 2-Fair; 3-Good; 4-Verygood and 5-Excellent. The per cent rotting of fruits (PRF) was calculated on the number basis by counting the number of rotten fruits $(\mathrm{Fr})$ and total fruits $(\mathrm{Ft})$ on each storage interval. The PRF was calculated as PRF $\left.=100[\mathrm{Ft}-\mathrm{Fr})(\mathrm{Ft})^{-1}\right]$. Total phenolics were estimated as per method described in AOAC (1980). The cellulase activity was estimated according to the procedure of (Mahadevan and Sridhar, 1982).

\section{Results and discussion}

It is evident from Tab. 1 that the cellulase activity varied significantly among different treatments and on storage interval during both the years of study. All the treatments showed progressive increase in cellulase activity with the advancement of storage period up to 20 days of storage, but afterwards the enzyme activity decreased towards the end of storage (Tab. 1). After 20 days of storage, the minimum cellulase activity was recorded in $\mathrm{CaCl}_{2}(2 \%)$ treated fruits followed by $\mathrm{GA}_{3} 60 \mathrm{ppm}$ treatment. Heavy influx of external calcium inhibits the ripening process due to reduction of enzyme activity. Presence of calcium ions limits the polyglacturonase activity in the cell wall of the fruit skin (Gleen and Pooviah, 1986). GA may have lowered the cellulase activity due to anti-senescence effect. External application of $\mathrm{Ca}$ increased the rigidity of cell wall. At the end of storage the enzyme activity was highest in $\mathrm{CaCl}_{2}(2 \%)$ treated fruits because these fruits contained the higher substrate content for enzyme activity as compared to other treatments, as the same was decomposed to a greater extent in other treatments with in 20 days of storage. Similar results was reported by (Mahajan, 1994) in apple.

High phenolics content is linked with higher resistance of fruits towards various pathological rots. Total phenolics content decreased with the advancement of storage period regardless of pre-harvest treatment (Tab. 2). Similar results were reported by Panwar (1981); Goel and Siddiqui (1999) in ber fruits. After 30 days of storage fruits treated with $\mathrm{CaCl}_{2}$ (2\%) exhibited maximum phenolics content $(0.090 \%$ and $0.093 \%)$ while it was minimum in control. Similarly in avocadoes, calcium compound treatments resulted in suppression of respiration and high phenolic content of the fruits (Rensburg and Engelbrecht, 1986)

At the time of harvesting the untreated fruits showed maximum palatability rating (Tab. 3). The pre-harvest treatments might have retarded the ripening process of ber fruits which led to low palatability as compared to untreated fruits. But, after 10 days of storage the PR of fruits increased in all the treatments except control, where it decreased. However with the advancement of storage period, there was continuous reduction in PR in all the treatments. At the end of storage, the maximum PR (3.50 and 3.70) was recorded in $\mathrm{Ca} \mathrm{Cl}_{2}(2 \%)$ treated fruits which was followed by $\mathrm{GA}_{3} 60 \mathrm{ppm}$ treatment. These preharvest treatments of $\mathrm{Ca}$ and $\mathrm{GA}_{3}$ might have delayed senescence process which resulted in maintenance of fruit

Tab. 1. Effect of different pre-harvest treatments on cellulase activity in ber fruit during cold storage.

\begin{tabular}{|c|c|c|c|c|c|c|c|c|c|c|}
\hline \multirow{4}{*}{ Treatment } & \multicolumn{10}{|c|}{ Cellulase activity } \\
\hline & \multicolumn{4}{|c|}{2002} & \multicolumn{6}{|c|}{2003} \\
\hline & \multicolumn{4}{|c|}{ Days after storage } & \multicolumn{6}{|c|}{ Days after storage } \\
\hline & 0 & 10 & 20 & 30 & Mean & 0 & 10 & 20 & 30 & Mean \\
\hline $\mathrm{CaCl}_{2} 0.5 \%$ & 0.88 & 1.15 & 2.20 & 1.54 & 1.44 & 0.85 & 1.17 & 1.97 & 1.53 & 1.38 \\
\hline $\mathrm{CaCl}_{2} 1 \%$ & 0.79 & 1.06 & 1.88 & 1.56 & 1.32 & 0.72 & 1.04 & 1.89 & 1.57 & 1.31 \\
\hline $\mathrm{CaCl}_{2} 2 \%$ & 0.70 & 0.92 & 1.78 & 1.73 & 1.28 & 0.65 & 0.80 & 1.80 & 1.76 & 1.26 \\
\hline $\mathrm{Ca}\left(\mathrm{No}_{3}\right)_{2} 0.5 \%$ & 0.88 & 1.20 & 2.26 & 1.40 & 1.43 & 0.86 & 1.17 & 2.07 & 1.49 & 1.40 \\
\hline $\mathrm{Ca}\left(\mathrm{No}_{3}\right)_{2} 1 \%$ & 0.82 & 1.16 & 2.03 & 1.50 & 1.38 & 0.72 & 1.07 & 1.98 & 1.54 & 1.33 \\
\hline $\mathrm{Ca}\left(\mathrm{No}_{3}\right)_{2} 2 \%$ & 0.74 & 1.01 & 1.85 & 1.60 & 1.30 & 0.68 & 0.96 & 1.92 & 1.61 & 1.29 \\
\hline $\mathrm{GA}_{3}-20 \mathrm{ppm}$ & 0.85 & 1.10 & 2.21 & 1.50 & 1.41 & 0.70 & 1.02 & 2.16 & 1.56 & 1.36 \\
\hline $\mathrm{GA}_{3}-40 \mathrm{ppm}$ & 0.70 & 1.02 & 1.85 & 1.60 & 1.29 & 0.65 & 0.96 & 1.90 & 1.64 & 1.28 \\
\hline $\mathrm{GA}_{3}-60 \mathrm{ppm}$ & 0.66 & 0.94 & 1.80 & 1.70 & 1.28 & 0.63 & 0.88 & 1.82 & 1.72 & 1.26 \\
\hline Bavistin $0.1 \%$ & 0.88 & 1.23 & 2.27 & 1.38 & 1.44 & 0.86 & 1.20 & 2.18 & 1.44 & 1.42 \\
\hline Control (untreated) & 0.90 & 1.98 & 1.63 & 1.30 & 1.45 & 0.89 & 1.89 & 1.65 & 1.32 & 1.44 \\
\hline Mean & 0.80 & 1.16 & 1.99 & 1.53 & & 0.75 & 1.10 & 1.94 & 1.56 & \\
\hline \multicolumn{11}{|l|}{$\mathrm{CD}(5 \%)$} \\
\hline Treatments (A) & $=$ & 0.0580 & & & & & 0.059 & & & \\
\hline Storage days (B) & $=$ & 0.0349 & & & & & 0.060 & & & \\
\hline Interaction $(\mathrm{A} \times \mathrm{B})$ & $=$ & 0.116 & & & & & 0.199 & & & \\
\hline
\end{tabular}


90

Tab. 2. Effect of different pre-harvest treatments on total phenolics of ber fruit during cold storage

\begin{tabular}{|c|c|c|c|c|c|c|c|c|c|c|}
\hline \multirow{4}{*}{ Treatment } & \multicolumn{10}{|c|}{ Total Phenolics } \\
\hline & \multicolumn{4}{|c|}{2002} & \multicolumn{6}{|c|}{2003} \\
\hline & \multicolumn{4}{|c|}{ Days after storage } & \multicolumn{6}{|c|}{ Days after storage } \\
\hline & 0 & 10 & 20 & 30 & Mean & 0 & 10 & 20 & 30 & Mean \\
\hline $\mathrm{CaCl} 20.5 \%$ & 0.104 & 0.098 & 0.088 & 0.078 & 0.092 & 0.103 & 0.098 & 0.089 & 0.076 & 0.091 \\
\hline $\mathrm{CaCl} 21 \%$ & 0.105 & 0.098 & 0.090 & 0.082 & 0.094 & 0.106 & 0.096 & 0.091 & 0.080 & 0.93 \\
\hline $\mathrm{CaCl} 22 \%$ & 0.108 & 0.103 & 0.098 & 0.090 & 0.100 & 0.110 & 0.107 & 0.099 & 0.093 & 0.102 \\
\hline $\mathrm{Ca}(\mathrm{No} 3) 20.5 \%$ & 0.102 & 0.096 & 0.084 & 0.066 & 0.087 & 0.103 & 0.098 & 0.086 & 0.070 & 0.089 \\
\hline $\mathrm{Ca}(\mathrm{No} 3) 2 \mathrm{1} \%$ & 0.104 & 0.098 & 0.087 & 0.074 & 0.091 & 0.105 & 0.098 & 0.088 & 0.076 & 0.092 \\
\hline $\mathrm{Ca}(\mathrm{No} 3) 22 \%$ & 0.107 & 0.103 & 0.092 & 0.084 & 0.097 & 0.108 & 0.102 & 0.092 & 0.085 & 0.097 \\
\hline GA3-20 ppm & 0.106 & 0.100 & 0.085 & 0.074 & 0.091 & 0.107 & 0.101 & 0.084 & 0.075 & 0.092 \\
\hline GA3-40 ppm & 0.107 & 0.103 & 0.096 & 0.084 & 0.098 & 0.108 & 0.105 & 0.097 & 0.086 & 0.099 \\
\hline GA3-60 ppm & 0.110 & 0.104 & 0.096 & 0.088 & 0.099 & 0.112 & 0.106 & 0.098 & 0.090 & 0.101 \\
\hline Bavistin $0.1 \%$ & 0.103 & 0.096 & 0.084 & 0.068 & 0.087 & 0.103 & 0.096 & 0.082 & 0.070 & 0.087 \\
\hline Control (untreated) & 0.102 & 0.086 & 0.070 & 0.057 & 0.078 & 0.103 & 0.088 & 0.062 & 0.059 & 0.078 \\
\hline Mean & 0.105 & 0.099 & 0.088 & 0.076 & & 0.106 & 0.100 & 0.088 & 0.078 & \\
\hline \multicolumn{11}{|l|}{$\mathrm{CD}(5 \%)$} \\
\hline Treatments (A) & $=$ & 0.0029 & & & & & 0.006 & & & \\
\hline Storage days (B) & $=$ & 0.0017 & & & & & 0.0039 & & & \\
\hline Interaction $(\mathrm{A} \times \mathrm{B})$ & $=$ & 0.0059 & & & & & NS & & & \\
\hline
\end{tabular}

health in storage. Similar results are obtained by Kumar $e t$ al. (1994) in 'Banarasi Pawandi' fruits.

After 20 days of cold storage fruit rotting was noticed in some treatments (control > Bavistin $0.1 \%>\mathrm{Ca}\left(\mathrm{NO}_{3}\right)_{2}$ $0.5 \%>\mathrm{CaCl}_{2} 0.5 \%$ ) while fruits from remaining treatments maintained their normal health. At the end of cold storage, the percentage of rotten fruits were significantly higher in untreated fruits as compared to all other treatments (Tab. 4). The fruit treated with $\mathrm{CaCl}_{2}(2 \%)$ registered minimum rotting followed by $\mathrm{GA}_{3} 60 \mathrm{ppm}$ treatment. An increase in calcium content of fruit has been associated with decreased incidence of physiological dis-

Tab. 3. Effect of different pre-harvest treatments on palatability rating of ber fruit during cold storage

\begin{tabular}{|c|c|c|c|c|c|c|c|c|c|c|}
\hline \multirow{4}{*}{ Treatment } & \multicolumn{10}{|c|}{ Palatability rating } \\
\hline & \multicolumn{4}{|c|}{2002} & \multicolumn{6}{|c|}{2002} \\
\hline & \multicolumn{4}{|c|}{ Days after storage } & \multicolumn{6}{|c|}{ Days after storage } \\
\hline & 0 & 10 & 20 & 30 & Mean & 0 & 10 & 20 & 30 & Mean \\
\hline $\mathrm{CaCl}_{2} 0.5 \%$ & 4.08 & 4.50 & 3.30 & 2.33 & 3.55 & 4.00 & 4.50 & 3.25 & 2.50 & 3.56 \\
\hline $\mathrm{CaCl}_{2} 1 \%$ & 3.91 & 4.60 & 3.90 & 2.80 & 3.80 & 3.83 & 4.60 & 4.00 & 3.00 & 3.86 \\
\hline $\mathrm{CaCl}_{2} 2 \%$ & 3.75 & 4.85 & 4.50 & 3.50 & 4.15 & 3.80 & 4.75 & 4.33 & 3.70 & 4.14 \\
\hline $\mathrm{Ca}\left(\mathrm{No}_{3}\right)_{2} 0.5 \%$ & 4.20 & 4.40 & 3.25 & 2.20 & 3.51 & 4.25 & 4.50 & 3.10 & 2.33 & 3.54 \\
\hline $\mathrm{Ca}\left(\mathrm{No}_{3}\right)_{2} 1 \%$ & 4.00 & 4.50 & 3.70 & 2.60 & 3.70 & 3.83 & 4.65 & 3.58 & 2.70 & 3.69 \\
\hline $\mathrm{Ca}\left(\mathrm{No}_{3}\right)_{2} \%$ & 3.80 & 4.70 & 4.16 & 3.20 & 3.96 & 3.75 & 4.70 & 4.10 & 3.25 & 3.95 \\
\hline $\mathrm{GA}_{3}-20 \mathrm{ppm}$ & 4.00 & 4.66 & 3.60 & 2.60 & 3.71 & 3.80 & 4.60 & 3.50 & 2.70 & 3.65 \\
\hline $\mathrm{GA}_{3}-40 \mathrm{ppm}$ & 3.80 & 4.80 & 4.00 & 3.20 & 3.95 & 3.70 & 4.75 & 4.10 & 3.30 & 3.96 \\
\hline $\mathrm{GA}_{3}-60 \mathrm{ppm}$ & 3.70 & 4.70 & 4.30 & 3.40 & 4.02 & 3.60 & 4.70 & 4.25 & 3.60 & 4.04 \\
\hline Bavistin $0.1 \%$ & 4.25 & 4.33 & 3.00 & 2.10 & 3.42 & 4.50 & 4.25 & 3.25 & 2.20 & 3.55 \\
\hline Control (untreated) & 4.66 & 4.00 & 2.40 & 1.60 & 3.16 & 4.50 & 4.00 & 2.50 & 2.00 & 3.25 \\
\hline Mean & 4.01 & 4.55 & 3.67 & 2.68 & & 3.96 & 4.54 & 3.63 & 2.84 & \\
\hline \multicolumn{11}{|l|}{$\mathrm{CD}(5 \%)$} \\
\hline Treatments (A) & $=$ & 0.161 & & & & & 0.190 & & & \\
\hline Storage days (B) & $=$ & 0.097 & & & & & 0.114 & & & \\
\hline Interaction $(\mathrm{A} \times \mathrm{B})$ & $=$ & 0.323 & & & & & 0.380 & & & \\
\hline
\end{tabular}


Tab. 4. Effect of different pre-harvest treatments on per cent rotting of ber fruit during cold storage

\begin{tabular}{|c|c|c|c|c|c|c|c|c|}
\hline \multirow{4}{*}{ Treatment } & \multicolumn{8}{|c|}{ Percent rotting } \\
\hline & \multicolumn{3}{|c|}{2002} & \multicolumn{5}{|c|}{2003} \\
\hline & \multicolumn{3}{|c|}{$\begin{array}{l}\text { Days after } \\
\text { storage }\end{array}$} & \multicolumn{4}{|c|}{$\begin{array}{c}\text { Days after } \\
\text { storage }\end{array}$} & \multirow[b]{2}{*}{ Mean } \\
\hline & 10 & 20 & 30 & Mean & 10 & 20 & 30 & \\
\hline $\mathrm{CaCl}_{2} 0.5 \%$ & *- & 0.90 & 2.10 & 1.0 & *- & 0.60 & 1.80 & 0.80 \\
\hline $\mathrm{CaCl}_{2} 1 \%$ & - & - & 1.34 & 0.44 & - & - & 1.25 & 0.42 \\
\hline $\mathrm{CaCl}_{2} 2 \%$ & - & - & 0.78 & 0.26 & - & - & 0.50 & 0.17 \\
\hline $\begin{array}{c}\mathrm{Ca}\left(\mathrm{No}_{3}\right)_{2} \\
0.5 \%\end{array}$ & - & 1.25 & 2.63 & 1.29 & - & 1.0 & 2.20 & 1.07 \\
\hline $\mathrm{Ca}\left(\mathrm{No}_{3}\right)_{2} 1 \%$ & - & - & 1.82 & 0.60 & - & - & 1.40 & 0.47 \\
\hline $\mathrm{Ca}\left(\mathrm{No}_{3}\right)_{2} 2 \%$ & - & - & 1.25 & 0.41 & - & - & 1.20 & 0.40 \\
\hline $\mathrm{GA}_{3}-20 \mathrm{ppm}$ & - & - & 1.92 & 0.64 & - & - & 1.50 & 0.50 \\
\hline $\mathrm{GA}_{3}-40 \mathrm{ppm}$ & - & - & 1.20 & 0.40 & - & - & 1.00 & 0.33 \\
\hline $\mathrm{GA}_{3}-60 \mathrm{ppm}$ & - & - & 1.10 & 0.36 & - & - & 0.80 & 0.27 \\
\hline Bavistin $0.1 \%$ & - & 1.30 & 3.74 & 1.68 & - & 1.20 & 3.50 & 1.57 \\
\hline $\begin{array}{l}\text { Control } \\
\text { (untreated) }\end{array}$ & - & 3.02 & 8.53 & 3.85 & - & 2.50 & 8.30 & 3.60 \\
\hline Mean & - & 0.59 & 2.40 & & - & 0.48 & 2.13 & \\
\hline $\mathrm{CD}(5 \%)$ & & & & & & & & $\begin{array}{l}\text { No } \\
\text { ting }\end{array}$ \\
\hline $\begin{array}{l}\text { Treatments } \\
\text { (A) }\end{array}$ & $=$ & 0.199 & & & & 0.218 & & \\
\hline $\begin{array}{l}\text { Storage } \\
\text { days }(\mathrm{B})\end{array}$ & $=$ & 0.104 & & & & 0.114 & & \\
\hline $\begin{array}{c}\text { Interaction } \\
(\mathrm{A} \times \mathrm{B})\end{array}$ & $=$ & 0.344 & & & & 0.379 & & \\
\hline
\end{tabular}

orders, improved storage life, reduced severity of bacterial and fungal rots (Raese 1986; Conway and Sams 1994) as calcium is known to impart resistance against the attack of infectious pathogens (Bangreth et al., 1972). Calcium compounds, significantly thickened the middle lamella of fruit cells owing to increased deposition of calcium pectate and thereby maintained the cell wall rigidity which inhibits the penetration and spread of pathogens in fruits (Gupta et al., 1984)). The prolongation of fruit life due to growth regulators was probably due to effectiveness of these chemicals in retaining of green pigments, retardation of ripening and senescence (Huang, 1974). These results are in line with findings of Gupta et al. (1987) who suggested that the pre harvest sprays of calcium compounds (Chlorides, Nitrates, Sulphates and Phosphates) reduced the decay loss in ber fruits.

\section{References}

A. O. A. C. (1980). Official methods of analysis of analytical chemists. Association of the Official Analytical Chemists, Washington, D.C.

Babbita, J. K. M. J. Powers and M. E. Patterson (1973). Effect of growth regulators on cellulase, polygalacturonase, respiration, colour and texture of ripening tomato. J Amer
Soc Hort Sci 98:71-81.

Bangreth, F., D. R. Dilley and D. H. Dewey (1972). Effect of post-harvest Calcium treatments of apple on internal breakdown and respiration of Apple fruits. J Amer Soc Hort Sci. 97:679-82.

Conway, W. S. and C. E. Sams (1994). Possible mechanism by which postharvest calcium treatment reduces decay in apples Malus domestica inoculation with Penicillium expansum. Phyto Pathology 74:208-10.

Gleen, G. M. and B. W. Poovaiah (1986). The role of calcium in delaying softening of apples. HortSci. 21:666.

Goel, A. and S. Siddiqui (1999). Changes in enzyme activities and physico-chemical characteristics of ber (Zizyphus mauritiana Lamk) cv. Umran as influenced by harvesting maturity. Indian J Agric Res 33:209-13.

Gupta, O. P., S. Siddiqui and K. S. Chauhan (1987). Evaluation of various calcium compounds for increasing the shelf life of ber (Zizyphus mauritiana Lamk) Fruits. Indian J. Agric. Res. 21:65-70.

Gupta, O. P., B. P. Singh, S. P. Singh and K. S. Chauhan (1984). Effect of calcium compounds as pre-harvest spray on the shelf life of peach cv. Sharbati. Punjab Hort. J. 24:105-10.

Gupta, O. P., P. C. Jindal and B. P. Singh (1980). Effect of preharvest spray of calcium nitrate on the storage behaviour of grapes cv. Perlette. J. Res. Haryana Agric. Univ. 10:204-06.

Huang, C. C. (1974). Maintaining freshness of pineapple fruits for export. Taiwan Agriculture Quarterly 10:103-11.

Kumar, D., C. B. S. Rajput and S. P. Singh (1994). Effect of calcium chloride and Bavistin on the post-harvest life of jujube fruits (Zizyphus mauritiana Lamk) cv. Banarasi Pewandi. Prog. Hort. 26:72-76.

Mahadevan, A. and R. Sridhar (1982). Methods in physiological plant pathology, Sivagami Pub. Madras.

Mahajan, B. V. C. (1994). Biochemical and enzymatic changes in apple during cold storage. J. Food Sci. Tech. 31:142-44.

Mehta, P. M. S. S. Raj and P. S. Raju (1986). Influence of fruit ripening retardants on succinate and malate dehydrogenase in papaya fruits with emphasis on preservation. Indian J. Hort. 43:169-73.

Panwar, J. S. (1981). Post harvest physiology and storage behaviour of ber fruit (Zizyphus mauritiana Lamk) in relation to temperature and various treatments $\mathrm{cv}$. Umran and Kaithli. Thesis Abstract. 64-65.

Raese, J. T. (1986). Nitrogen and calcium important in determining yield, fruit quality and disorders of 'Anjou' pears. pp 155-68. In. Proc. Pac. Northwest Tree Fruit ShortCourse.

Rensburg, E. Van. and A. H. P. Engelbrecht (1986). Effect of calcium salts on susceptibility to browning of avocado fruit. J. Food Sci. 51:1067-68.

Salunkhe, D. K. and S. S. Kadam (1995). Handbook of Fruit Science and Technology pp 387. Marcel Dekker Inc., New York. 